\title{
Hydralazine Hydrochloride
}

National Cancer Institute

\section{Source}

National Cancer Institute. Hydralazine Hydrochloride. NCI Thesaurus. Code C551.

The hydrochloride salt of hydralazine, a phthalazine derivative with antihypertensive and potential antineoplastic activities. Hydralazine alters intracellular calcium release and interferes with smooth muscle cell calcium influx, resulting in arterial vasodilatation. This agent also inhibits the phosphorylation of myosin protein and chelation of trace metals required for smooth muscle contraction, resulting in an increase in heart rate, stroke volume and cardiac output. In addition to its cardiovascular effects, hydralazine inhibits DNA methyltransferase, which may result in inhibition of DNA methylation in tumor cells. 